\title{
Ad divinarum rerum cognitionem. Petrus Mosellanus and Jacobus Latomus on biblical or scholastic theology
}

\author{
WIM FRANÇOIS
}

La question de savoir comment les théologiens pouvaient arriver à une meilleure connaissance de Dieu était au cour du débat du XVI siècle entre théologiens catholiques et humanistes. Cet article propose une étude des différentes positions de l'humaniste de Leipzig, Petrus Mosellanus, et du théologien de Louvain, Jacobus Latomus (1518-19). Le premier avance que l'homme peut se rapprocher du mystère de Dieu par l'étude des Écritures saintes, alors que le deuxième affirme que c'est avec l'aide des scolastiques que les théologiens peuvent se rapprocher des choses divines. Cet article examine en particulier les présupposés sémantiques et épistémologiques qui sous-tendent la pensée de Mosellanus et de Latomus.

$\mathrm{T}$ he question concerning how theologians arrive at knowledge (cognitio) about "divine things" (res divinae) was at stake in debates between sixteenth-century humanist and catholic theologians-debates that centred on pedagogics, or the appropriate training of future theologians and the attendant semantic and epistemological presuppositions. In this article, I focus on the Leipzig humanist Petrus Mosellanus and the Louvain theologian Jacobus Latomus. By the autumn of 1518, Mosellanus's plea in favour of the study of the three biblical languages had become known at the University of Louvain. ${ }^{1}$ This study was considered a necessary condition for a theology based on Scripture, since it was believed that God had revealed himself primarily in Scripture. At about the same time, the masters of the University had (likewise) become familiar with Erasmus's Ratio verae theologiae, which shared a similar point of view. Moreover, Louvain had seen the start-up of the Collegium Trilingue, which was the result of the biblical humanists' aspirations with regard to language instruction. The Louvain theologians had become some- 
what concerned with the "humanist offensive" that aspired to win over the University to its cause, including the Faculty of Theology. The magistri Lovanienses sent one of them, Jacobus Latomus, into the line of fire in order to respond to the biblical humanists and to defend scholastic theology as the most adequate way to treat the "divine things." In the same line, Latomus defended the auxiliary sciences of scholastic theology, i.e. Aristotelian philosophy and dialectics. In the spring of 1519, he published his Dialogue about the knowledge of the three languages and the study of theology. ${ }^{2}$ This treatise was a thinly concealed rejoinder to the Oratio of Mosellanus. By tackling the relatively unknown Mosellanus, Latomus's prime objective was to hit out at the famous, unassailable Erasmus. Although Latomus replies directly to several positions held by Erasmus, as Erika Rummel has rightly proved, ${ }^{3}$ our article focuses on the positions of Mosellanus and Latomus in the context of pedagogical controversy.

\section{Mosellanus's De variarum linguarum cognitione paranda oratio}

\subsection{Petrus Mosellanus in Leipzig}

Because Mosellanus is not a widely known humanist, it may be beneficial to start with some biographical information. ${ }^{4}$ Peter Schade was born in 1493/94 in Bruttig, in the neighbourhood of Cochem-on-the-Moselle, which explains the origin of his Latin name "Mosellanus." In 1509, the particularly gifted young man went to Cologne University. At the Cologne arts faculty, Mosellanus received the traditional education in dialectics, grammar, and rhetoric, which he completed in 1512 with a bachelor's degree. The young Peter, however, felt more comfortable in the less conventional humanist circles of the city, where he received a solid education in Latin and Greek.

Mosellanus left Cologne, probably in the winter of 1513-14, and moved to Saxony. ${ }^{5}$ He first became a teacher of Greek in Freiberg-in-Saxony, at the schola latina et christiana. In the spring of 1515, he registered at the University of Leipzig, which was still dominated by established scholastic scholarship. Nevertheless, the humanist movement was strongly supported by Duke Georges of Saxony. ${ }^{6}$ In Leipzig, under the guidance of the Englishman Richard Crocus, Mosellanus perfected his knowledge of Greek. In order to earn a living, he remained active as a teacher of Greek and Latin, a profession

he had most likely begun in Cologne. He also published two companions of classical Latin. The most successful proved to be his Paedologia in puerorum usum conscripta. The work was first edited in 1518, but it was subsequently reprinted several times. It contains several day-to-day conversations and 
dialogues between teachers and students and between students themselves, which was a literary form humanists used frequently in order to teach their pupils beautiful classical Latin.

Mosellanus's teacher, Richard Crocus, left the University of Leipzig in 1517 and was succeeded in his position as professor of Greek by his outstanding pupil. Mosellanus's famous inaugural speech was published in August 1518 under the title De variarum linguarum cognitione paranda oratio. The spirit and thrust of the speech reflected the influence of Erasmus, with whom Mosellanus had begun to correspond. It is this Oratio that I will discuss in further detail. The Oratio provoked reactions in scholastic circles, especially in Leipzig and Louvain (where Latomus lived).

The opposition Mosellanus encountered among established scholastic circles must have confirmed the critical views on the Church that he and likeminded humanists had formed and expressed. It explains why Mosellanus and others felt quite attracted to the early stages of the Reformation. Upon Duke Georges of Saxony's request, it was Mosellanus who, at the end of June 1519, delivered the opening address at the Leipziger Disputation, ${ }^{7}$ whereas Luther and Karlstadt engaged in an argument with Eck. Mosellanus called on the participants to exercise modesty and moderation. At stake was the discussion about indulgences and the authority of pope and councils. The outcome of the Leipziger Disputation, however, proved to be a great disappointment, because it did not bring about the much hoped-for reconciliation. Instead, it marked the beginning of an ever-widening gap between Mosellanus and the more refined humanist circles on the one hand, and Luther and the early Reformation movement on the other. From that point onwards, Mosellanus identified himself solidly with Erasmian humanism, which (for the time being) had not yet taken sides with or against either of the two parties, and had assumed a very tolerant stance. ${ }^{8}$

In Leipzig, Mosellanus did succeed, in spite of immense opposition, in gathering around him a group of like-minded students. Moreover, he published an impressive number of works by classical authors. ${ }^{9}$ Mosellanus and the other Leipzig scholars could readily call upon the well-developed art of printing in the city.

In the 1520s, Mosellanus's academic career experienced a dramatic rise, in spite of fierce opposition from certain established scholastic milieus. Duke Georges continually intervened in the organization of academic life on behalf of his protégé, who was awarded the degree of magister artium on January 3, 1520. From then on, Mosellanus no longer confined himself to the teaching of Greek language and literature, but also sought to obtain a degree in theology. He received the degree of baccalaureus biblicus in August 1520, 
while lecturing on Scripture and Augustine. He was appointed rector of the University of Leipzig for the summer semester of the same year. Also in June 1520, again at the intercession of the Duke, Mosellanus was accepted into the so-called grossen Fürstencollegium, a well-paid and honorable benefice reserved for the most privileged members of the university community. It was highly exceptional that a humanist-minded professor was granted such status. 10

In 1523, Mosellanus was again appointed to the post of rector of the University of Leipzig for the summer semester. On November 9, 1523, Mosellanus might have obtained from the Faculty of Theology the degree of baccalaureus sententiarius. ${ }^{11}$ In principle, this implied that he had to lecture on the Sententiae of the great scholastic theologian Peter Lombard, an occupation considered useless and boring by biblical humanists. The degree was most likely awarded after the intercession of the Duke. Only a few months later, on April 19, 1524, Mosellanus died, barely 31 years old. ${ }^{12}$

\subsection{Knowledge of Hebrew, Greek, and Latin as prerequisites for a biblical theology}

In his treatise De variarum linguarum cognitione paranda oratio, ${ }^{13}$ Mosellanus advocated a radical reform of the trivium, in which, alongside (classical) Latin, both Greek and Hebrew could be allotted a proper place. Knowledge of these three languages (and the study of the classical authors) was a prerequisite for the study of different sciences, and particularly for the study of theology, which was equal to the unfolding of Scripture. ${ }^{14}$ According to Mosellanus, it was not indelicate to distance oneself from the Latin Vulgate. ${ }^{15}$ The more theology attempted to find connections to the (original text of the) Scriptures, the closer it came to the divine mystery of faith. Mosellanus also emphasized that meditation on the Scriptures and thus on the mystery of God must be embraced with a pious heart, in a serene, moderate way and free of all worldly passions. Such an admonition might have been influenced by the Fathers or by Pauline theology (and perhaps by mystical theology). While praising a theology based on Scripture, Mosellanus criticized all theological practice that used "barbarous" medieval Latin, relied on dialectics, and whose doctrinal syntheses were based primarily on Aristotelian philosophy rather than on biblical sources. He held that the complicated theological constructs of scholasticism have led to the obscuring of divine truth, to carelessness in language, and to the provocation of disputes. For such pointed controversies Mosellanus had nothing but the utmost aversion. He stated that this kind of theological practice had plunged the Church into discord, as was made painfully clear in his time. ${ }^{16}$ Mosellanus's views 
were completely in line with those held by his role model, Erasmus. He used a similar imagery that Lorenzo Valla, Erasmus and other biblical humanists had borrowed from Jerome, ${ }^{17}$ and referred to the pure sources and the turbid streamlets filled with mud, which—for his part—stood for the original text of Scripture and Latin language scholastic systems respectively. ${ }^{18}$

As for a theologian's essential need to know languages, Mosellanus brought up several arguments. For one, there was the purely speculative argument that the divine reality should always be considered multilingual. God, his angels, and saints were believed to master several languages in order to be able to understand the pleas and prayers of all human beings. ${ }^{19}$ On the other hand, human reason (ratio) could not but express itself through language (oratio). Language was perceived as the outward expression of reason, without which the latter meant nothing. Thus, the more languages a person knew, the better that person resembled the image of a multilingual God (and the further he left behind the animal). ${ }^{20}$ Where this divine multiplicity of languages ${ }^{21}$ implied that a person could pray to God in any language, including the vernacular, the subject of using a vernacular Bible text is not touched on by Mosellanus.

Mosellanus also referred to biblical arguments. In the dedication of his book to Duke Georges of Saxony, Mosellanus had already indicated that the three languages on the inscription at the top of Jesus's cross had been sanctified by his blood. It followed that these languages testified to his divinity and humanity, his life, death, and resurrection. This argument was shared by several humanists, in fact it was even used in the Middle Ages and was based upon an old patristic tradition. Mosellanus, for his part, referred explicitly to Jerome, who undoubtedly was one of the humanists' favourite Fathers. ${ }^{22}$ Furthermore, in his Letter to the Corinthians, Paul ${ }^{23}$ described the knowledge of languages as one of the most important gifts of the Holy Spirit, "putting it on an equal footing, though not preferring it, to the gift of prophecy, which is perhaps the greatest of all.” This motive was taken up many times by Mosellanus. (This same Paul declared that conceited questions should be avoided, as should hollow disputes that served completely no purpose and moreover gave rise to disagreement). ${ }^{24}$ Furthermore, at Pentecost the Holy Spirit descended upon the apostles in the form of fiery tongues and taught them to speak in many languages. ${ }^{25}$ It was in these languages that the apostles had to proclaim faith in Christ to the whole world. To this end, they had at their disposal the Holy Scriptures as their foremost and mightiest means of persuasion. The knowledge of the biblical languages was therefore an essential auxiliary discipline. ${ }^{26}$ 
Mosellanus's enthusiasm for languages went so far that he saw the future of Christianity also depending on the appeal to the original biblical word. He felt that the reliance on Aristotelian philosophy and dialectics was counterproductive, as the deplorable situation of Christianity in the sixteenth century made painfully clear. ${ }^{27}$ Here, too, it is striking that Mosellanus did not once make an express link between the preaching of the gospel to the peoples and the use of the Bible in the vernacular. Did Mosellanus not touch on this subject because he considered it irrelevant for his topic (i.e. the promotion of the three biblical languages) or inappropriate to the university environment in which he gave his speech? Or was Mosellanus's opinion in 1517-18 still that the study of the Scriptures was only conceivable in Greek and Hebrew (next to Latin)? If the latter case, he distanced himself from Erasmus who had explicitly advocated since 1515-16 that the Bible should be made available in the vernacular. In his list of biblical arguments, Mosellanus also quoted Christ's precept taken from Mt 5:18, according to which, "no jot or tittle” of Scripture must be neglected. Mosellanus asked the rhetorical question: how can this precept be fulfilled without a knowledge of the biblical languages?28

In addition to the Bible, Mosellanus made reference to the example of the Church Fathers. As was customary in humanistic circles, he referred especially to Jerome, Origen, Augustine’s De doctrina Christiana, and others. ${ }^{29}$ Mosellanus emphasized that Origen had already reached a relatively old age when he began to study Hebrew, which enabled him to take a critical stance on different formulations in the Septuagint and to compose the Hexapla. ${ }^{30}$ Jerome too, had mastered the Hebrew language. ${ }^{31}$ The favourite Church Father of the biblical humanists, Jerome was even allotted a word in a long prosopopoeia. ${ }^{32}$ In this he repeated and supported Mosellanus's criticism of scholastic theology and his plea for a scriptural theology based on the knowledge of languages. ${ }^{33} \mathrm{He}$ admitted that, among other things, the discrepancies between the different (Latin) translations of his time caused confusion. In order to draft a new, emended version of the Latin Bible, he judged it necessary to study the original biblical languages and to draw from the source texts themselves. ${ }^{34}$ Moreover, Augustine had stated in the second book of De doctrina Christiana that Latin-speaking people had to learn the other biblical languages in order to go back to the "original" text of the Bible and to escape the confusing variety of Latin translations. Therefore, Augustine returned to the study of Greek, which he had dropped in his early youth, frightened off by the difficulty of language study. In connection to this, Mosellanus referred to the Confessiones. ${ }^{35}$ The Church Fathers not only functioned as an example for the study of languages; they also exercised in a splendid manner a theol- 
ogy based on Scripture. The precise interpretation of what the above-named Church Fathers actually proposed in the area of language study and scriptural theology became a matter of debate between humanist and scholastic theologians.

Furthermore, the Church Fathers had an influence on papal decrees. ${ }^{36}$ A canon of the Decretum Gratiani (1140) entitled Ut veterum expressly decreed that the Old Testament should be emended on the basis of the Hebrew original, and the New Testament on the basis of the Greek original. This canon was almost a verbatim quotation from Letter 71 of Jerome (to Lucinius Baeticus), ${ }^{37}$ and was not based on Augustine, as was sometimes assumed. According to Mosellanus, the decree Inter sollicitudines - one of the decrees which Clement V had promulgated following upon the Council of Vienne (1311-1312) — also recommended instruction in the biblical languages Latin, Greek, and Hebrew at some institutions for priests and clerics. ${ }^{38}$ This, however, was a misrepresentation: the decree stipulated that the universities of Paris, Oxford, Bologna, and Salamanca should each appoint two masters for the instruction of Hebrew, Arabic, and Chaldean (Aramaic) with a view to missionary efforts among Jews and Muslims, particularly in Spain. ${ }^{39}$

Mosellanus also expressly referred to the authoritative example of his role model Erasmus, who, as a Jerome of the sixteenth century, had based an authentic biblical theology on the study of languages, and had distanced himself from scholastic theology. Erasmus was also praised for his efforts to restore the Church Fathers to honour. ${ }^{40}$ On the other hand, Mosellanus criticized the monks who from atop their pulpit fulminated against Erasmus and against all those who devoted themselves to the study of the biblical languages and to text criticism; ${ }^{41}$ that kind of criticism was a veritable topos in the humanists' work. Mosellanus underlined that Erasmus was doing nothing other than what the Church Fathers and popes had requested.

It goes without saying that Mosellanus also referred to prominent poets and figures from classical Antiquity in order to promote the study of Greek and to prevent students from shirking the difficulties associated with language studies. He encouraged them to follow, among others, the examples of Cato, who had begun studying Greek as an old man, and Mithridates, who was not prevented by politics and warfare from learning 22 languages. ${ }^{42}$

Mosellanus also gave reply to the argument often heard among the opponents of language study who claimed that the Greeks, when they had broken away from the Latin Church, had deliberately falsified their manuscripts of the New Testament, and that as a result the Latin text should not be emended on the basis of the Greek New Testament. Mosellanus elaborately explained that this argument was invalid, as a simple consultation of the Greek manu- 
scripts, many of which were also preserved in Western European countries, would prove. ${ }^{43}$

Furthermore, Mosellanus was pleased to find sovereigns and princes supporting the cause of language instruction and (as a consequence) the study of the Scriptures. ${ }^{44}$ In this respect, reference was made to the efforts of Pope Leo X and King Francis I of France. Charles V was known to support language experts such as Erasmus, and he had appointed experts of the three biblical languages to teaching posts in his Academy in Louvain, the Collegium Trilingue. In addition, Duke Georges of Saxony was praised for his efforts to introduce a Greek language course at Leipzig University.

\subsection{Semantic and epistemological background to the preoccupation with languages}

Mosellanus's emphasis on the usefulness of languages in biblical theology and other professions was expressly founded on Aristotle's semantic system describing the relationships among things, concepts, and words. ${ }^{45}$ In the early modern period, Aristotle's triadic system as developed in the Peri Hermeneias (traditionally translated as De Interpretatione), and commented upon by Ammonius (c. 440-520), Boethius (480-524/25), Thomas Aquinas (1225-1274), and others, was still generally accepted. ${ }^{46}$ It stated that on the basis of empirical observation of concrete objects in reality (res), affections arose and abstract concepts were formed in the observer's mind (passiones animae and conceptus). Affections and concepts were the same for all people, whatever their language, since the things of which the affections were the conceptual similitude in the mind, were the same for everyone. In this sense, it could be said that the concepts "signified" in a natural manner (and did not belong to a particular language). The human mind communicates by using both spoken sounds and written marks (voces and verba). Words are not the same for all, since no word is a name naturally, but only becomes significant by human convention or imposition.

In his Oratio, Mosellanus referred first to objections that might be raised by opponents of serious language study. Using Aristotle's system, such opponents stressed that "the object of science consisted of the subjectmatter itself, the res, and not of the concrete words about it, the verba; this subject-matter situated itself on the level of the heart, in pectore, and not on the level of the languages, linguae."47 Mosellanus undoubtedly alluded to the epistemological views of late medieval scholastics. ${ }^{48}$ The allusion of Mosellanus made clear that late medieval scholastics, and particularly the realist wing among them, intended to get a grip on the res, the objects as they were. They strongly emphasized the priority of reality over language. 
Words or verbal expressions are of secondary importance. Hence, scholastics strongly stressed the oratio mentalis which signified the res. The oratio mentalis can be described as a conceptual reasoning consisting of inner words or abstract concepts, and not belonging to any concrete language. According to the scholastics, philosophical and scientific discourse had to fit in with this conceptual reasoning.

Humanists, however, disliked the scholastics' abstract conceptual language. Mosellanus had no problem aligning himself with the view that on the basis of the sensory perception of many individual phenomena, universal concepts were formed in the mind, which then, in turn, were signified through words. Still, he adopted a clear position in explaining that concepts or notions had no power or value in themselves. He was not inclined to let an abstract concept-disconnected from a concrete spoken language-function as an essential intermediary between word and reality. According to Mosellanus, notions or concepts always needed to be expressed through concrete words and languages. ${ }^{49}$ He invoked the authority of Aristotle himself, who had defined words, according to Mosellanus's interpretation, "as the closest signs of the things formulated as concepts in the mind.” Hence, Mosellanus postulated an inextricable and mutual connection between the concept captured in concrete words (verba) and the objects of reality (res), between the signifying word and the signified reality. ${ }^{50}$ Mosellanus then made a shift from Aristotelian linguistics to rhetorical categories. In order to maintain the principle of rhetoric's unity of reality and language, ${ }^{51}$ he referred to Crassus's words in Cicero's De Oratore: "Every speech consists of matter and words, and the words cannot fall into place if you remove the matter, nor can the matter have clarity if you withdraw the words." 52 In short, in order to obtain a good grip on the different things of reality, it was necessary for scholars and students to be familiar with words and text. It was akin to cracking a hard nut and having to remove the shell before gaining access to the delicious fruit within. ${ }^{53}$ This explains why, according to the humanists, mastery of the relevant languages, of rhetoric and grammar, was indispensable. For the practice of theology, this theory implied that all those whose aim was to gain insight into the divine things should concentrate on the words of Scripture. The study of Scripture for its part required mastery of Hebrew and Greek. ${ }^{54}$

\section{Latomus's De trium linguarum, et studii Theologici ratione dialogus}

\subsection{Jacobus Latomus in Louvain}

Jacobus Latomus ${ }^{55}$ was born around 1475 under the name of Jacques Masson, in a little place called Cambron, between Ath and Mons in Hainaut, located in 
the southern part of the Low Countries. As a French speaking resident of these countries, Latomus went to Paris to study arts at the Collège de Montaigu. He lived in the connected collegium pauperum; the institution, which was led by Johannes Standonck, provided a thorough moral and religious education to men destined for clerical or religious life.

In 1499-1500, Latomus followed Johannes Standonck to Louvain, after the latter had been banished from Paris. Once again he joined Standonck's community for poor students, which in Louvain was connected to the socalled Pedagogy of the Pork ("Porcus” or “'t Verken”). Jacobus Latomus, who had finished his arts studies in Paris, gave courses to the students of the Pedagogy. ${ }^{56}$ At the same time, he studied theology at the Louvain Faculty, which perhaps was only a continuation of studies he had already begun in Paris. In 1510, Latomus received his licentiate in theology.

During this period, Latomus was not opposed to the humanist ideal of the study of languages and the interest in bonae literae, the classical literature of ancient Greece and Rome (as far as it was in harmony with Christian faith). There are even indications that Latomus taught rhetoric, the pre-eminent humanist discipline, at the Pedagogy of the Pork. He obviously liked reading (Latin) poetry and rhetoric. However, he did not know Hebrew and Greek. These facts prove that the traditional antithesis between the so-called conservative Louvain theologians and the enlightened humanists is an outmoded cliché. ${ }^{57}$

Still another issue makes clear that Latomus was not a fossilized representative of the old regime, but that he was open to certain ideas that were simmering in catholic reform-minded circles in the fifteenth and sixteenth centuries. In a quaestio quodlibetica in the year 1516, 1517, or 1518, Latomus pleaded for a better education of the clergy. One of his suggestions was the foundation of colleges in accordance with the model of the Standonck-houses in Paris and Louvain, where an intellectual education as well as a moral and religious formation were given to future priests. Moreover, he defended the residence of the clergy, the obligation for priests to reside where they exercised their pastoral care. He also supported a ban on combining ecclesiastical benefices. With regard to this latter abuse, he did not hesitate to point out the great responsibility of the pope and the Roman curia. These rather innovative ideas, supported by such people as Standonck, Latomus, and others, would only be realized later on by the Council of Trent.

Even though Latomus was favourably disposed towards the bonae literae and pleaded for reformations regarding the education of the clergy and pastoral care, he was opposed to the humanists' criticism of scholasticism and their wish to base theology on a thorough grammatical and philological 
study of Scripture, for which they considered a knowledge of Hebrew and Greek indispensable. The founding of the Collegium Trilingue in autumn 1517 and, even more, the circulation of Erasmus's Ratio verae theologiae and Mosellanus's Oratio in Louvain University circles in the autumn of 1518, gave rise to concern among the Louvain theologians. Around the turn of the year 1518-19 the tension was still mounting after a collection printed at Froben in Basel, and containing some tracts of Luther, began circulating in Louvain. The Louvain theologians suspected Erasmus of having collaborated on this collection and having authored the beautiful Latin forewords; they based their suspicion on the fact that Erasmus had stayed in Basel during the summer of 1518.58 This succession of events inspired the Louvain theologians to create a counter-offensive. Latomus, who was on the brink of his doctoral promotion, was put in charge of formulating a reply to the biblical humanists and writing a defence of the Louvain theologians' point of view.

At the beginning of March 1519, an incident occurred that became the catalyst of the controversy between humanists and the Louvain theologians. On Sunday the $6^{\text {th }}$ of March 1519, Alardus of Amsterdam posted an announcement at the door of St. Peter's church in Louvain. In this way he informed the public that on the day after Ash Wednesday he would start his lectures on a theological work of Erasmus. He would do this under the auspices of the Collegium Trilingue. The work of Erasmus in question was obviously the Ratio verae theologiae. ${ }^{59}$ The day after the placard appeared at the door of St. Peter's, the academic council of the University, at the behest of the leader of the theologians, Jean Briard, decided that Alardus would not be granted permission to give lectures on a theme that lay within the sphere of interest of the Faculty of Theology. It is probable that Latomus had already begun working, months before, on a refutation of the ideas of Mosellanus and Erasmus, but it is also possible that the incident with Alardus accelerated the publication of Latomus's work. Just a few days after the posting of Alardus's announcement, Latomus published his work De trium linguarum, et studii theologici ratione dialogus as an answer to Mosellanus's Oratio (and indirectly to Erasmus's Ratio). ${ }^{60}$ It is a dialogue between three figures: Petrus, Albertus, and Johannes. Petrus is a student in the faculty of arts. He is an adherent of humanism and is defending the propositions of Mosellanus. Albertus is about to begin his studies and is asking which discipline he should choose. Johannes is an older student of theology who is refuting the assertions of Petrus and who answers the questions of Albertus. Johannes, whose name is obviously an allusion to Jean Briard, the leader of the Louvain theologians, is the mouthpiece of Latomus and his colleagues at the Faculty of Theology. In the Dialogus, Johannes very often refers to a senex, his former teacher who 
is absent now and may be identified as Adrian of Utrecht. In addition to the use of the name "Petrus," the conversation is set in Leipzig, a day after the Greek lessons have begun there. These allusions show that Petrus Mosellanus was indeed envisaged. In the Apologia pro Dialogo of 1525, Latomus would admit that his Dialogus had been aimed at Mosellanus. ${ }^{61}$ Erasmus understood that the Dialogus was indirectly meant as a retort against him and his humanist views. Only a few days after the publication of Latomus's work, Erasmus published his answer, the Apologia ad Latomum. ${ }^{62}$

In 1519, Latomus earned his doctoral degree. After his promotion, he became professor legens et regens in the Faculty of Theology. He also became a member of the strict college, the council of the Faculty. Nevertheless, he was not yet professor ordinarius, and hence did not have the privilege to give lectures during the academic year. Latomus gave his lectures during the holidays. He was also dean of the Faculty during the years 1520, 1526, and 1529.

Latomus was not only involved in the controversy with Erasmus and his adherents. His theological career was particularly marked by controversy with Luther. In the spring of 1520, Luther had formulated an answer regarding his condemnation by the theologians of Cologne and Louvain. Latomus formulated his reply during the courses he gave the following holiday of 1520. His lectures were published in May 1521 under the title Articulorum doctrinae fratris Martini Lutheri per theologos Lovanienses damnatorum ratio ex sacris literis et veteribus tractatoribus. It was the first printed book in the Low Countries published to combat Luther's ideas. It stood at the beginning of an intensive controversy with Luther and other reformers. On several occasions, Luther indicated that he saw Latomus as his most serious opponent. ${ }^{63}$ Latomus did not limit his struggle against the Reformation to a pure academic discourse. He also acted regularly as a theological adviser of the Inquisition.

In 1526, Latomus was appointed as a canon of Our Lady's church in Cambrai. In accordance with his own principles regarding the residence of the clergy, Latomus resided principally in Cambrai from the summer of 1529. He only returned to Louvain in 1535 after he had succeeded Johannes Driedo as professor ordinarius. ${ }^{64}$ At the same time, he also received a prebend at St. Peter's church in Louvain. In 1537, Latomus held the office of rector of the University. On May 29, 1544, Jacobus Latomus died in Louvain. 


\subsection{Semantic and epistemological background to Latomus's plea for scholastic theology}

In his treatise De trium linguarum, et studii Theologici ratione dialogus, ${ }^{65}$ Latomus firstly criticized Mosellanus's semantic and epistemological premises. ${ }^{66}$ In the view of the Louvain theologian, the Leipzig humanist attached too much value to the elegant expression of words per se, as if words provided an immediate access to reality. He seems to disagree with the strong emphasis Mosellanus placed on the voces or verba as the proxima signa of concepts and things. Latomus and the other Louvain theologians who belonged to the via antiqua tradition, or the realist wing among scholastics, insisted that abstract concepts took precedence over concrete words. Reality was thus first understood by intellect before it could be expressed by means of words. All human beings who had observed reality shared the same concepts, because reality was the same for everybody. Hence Latomus's mouthpiece, Johannes, argued that concepts were the natural signs of the things. Concepts did not belong to a particular language; they were "nullius linguae.” They could be expressed in whichever language and were universally understood. I will discuss in further detail the main consequence of these premises, i.e. that one could have a grasp of a subject without understanding the specific words in which it was expressed. ${ }^{67}$ Latomus's theory is ultimately based upon Aristotle's triadic system. ${ }^{68}$ Yet the way he interprets and articulates the philosopher's theory reminds us of Augustine's De doctrina Christiana, ${ }^{69}$ his De Trinitate, ${ }^{70}$ and possibly also of his Sermo CCLXXXVIII. In natali Joannis Baptistae. De voce et verba. ${ }^{71}$

As indicated, medieval scholastics emphasized the importance of the oratio mentalis, which can be described as a form of conceptual reasoning consisting of inner words or abstract concepts. The oratio mentalis did not belong to any concrete language and preceded any spoken language. Scholasticism, which encompassed philosophy, theology, and sciences taught at schools and universities, was directed towards revealing this oratio mentalis. The conceptual technical language used by scholastics was considered as the most appropriate medium through which this oratio mentalis was expressed. ${ }^{72} \mathrm{~A}$ similar point of view was reflected in the scholastics' proposition that science was about res and not about verba. ${ }^{73}$ With the term res, scholastics meant reality captured in concepts, with verba the expression of it in a concrete language.

These ideas can explain Latomus's opposition to a humanism that required greater attention to the study of concrete languages and rhetoric. In the view of the Louvain theologian, reality could be perfectly known by people 
who did not know the concrete words. The study of words was by no means the condition for the understanding of reality. It was therefore deemed incorrect to spend too much time and attention on concrete wording. Of much greater importance was the ability to grasp the reality or res as such. If people had a mental grasp, then the concrete expression in verba naturally followed. ${ }^{74}$

\subsection{Latomus's plea for scholastic theology and its auxiliary sciences of dialectics and Aristotelian philosophy}

It is not difficult to see the implications of these ideas. ${ }^{75}$ According to the scholastics, theology concentrated on the knowledge of God and "the divine things," the "res divinae." As a consequence, concrete texts and languages were not believed to be indispensable. Latomus was convinced that "the gospel in the heart" or evangelium in corde took precedence over the written Bible. The Louvain theologian undoubtedly knew that "God's law written in (the tables of) the believer's heart" was a biblical notion. ${ }^{76}$ The question emerges, however, as to how Latomus actually interpreted the term evangelium in corde. Latomus (and his Louvain colleagues) argued that God "with his finger" had written his law in the hearts and the minds of the apostles and the first believers. God's original revelation to the first believers had not been realized through a concrete language, but had consisted only of internal, clear, and lucid concepts, i.e. an oratio mentalis. ${ }^{77}$ Latomus even thought that Jesus, his apostles, and Paul used a kind of conceptual, somewhat technicalscholastic language to communicate with insiders and learned men. However, when preaching to the illiterate masses they simplified the message by means of parables and similitudes. ${ }^{78}$

At a later point in time, inspired by God's Holy Spirit, the apostolic men produced a written version of the original oral message concerning Jesus's words and deeds, and doctrines and practices of the apostolic Church. ${ }^{79}$ Latomus confirmed that Scripture was the inspired Word of God. It contained the first written reflection of the Truth that God had revealed to the apostles. Scripture had therefore a great authority and the Church was bound by its essential content. ${ }^{80}$ Still, it remained obscure and ambiguous because of the use of many rhetorical techniques, such as images and parables. Moreover, neither all the words and deeds of the Lord nor the whole preaching and sacramental practice of the apostolic Church were included in Scripture; Jesus and the apostles had also conversed on the content of revelation in a scholastic-conceptual language, and of that part of the preaching, little or nothing was retained in Scripture. ${ }^{81}$

In Latomus's opinion, the most complete and clearest reflection of divine revelation was to be found in the evangelium in corde; but the question 
remained, where could the faithful find it? In Latomus's view, it had to be identified with Tradition, the depositum fidei, which dated back to the time of Jesus and the apostles and which had been handed down from generation to generation in the Church by means of an uninterrupted chain of partially oral accounts. ${ }^{82}$

In Latomus's view, the Church Fathers had played an important role in the process of handing down this Tradition. In their writings they had in fact preserved several teachings and practices which were not included in Scripture, in addition to interpretations which elucidate the content of the canonical Scriptures. ${ }^{83}$

Nevertheless, the Church Fathers before Augustine had treated the "divine things" in a free, rhetorical way. As a consequence, the borderline between orthodoxy and heresy in the works of the Fathers was rather vague. Sometime later, these writings came to be considered somewhat suspect and deceptive. Therefore, certain conventions, rules, and clear doctrinal formulations were introduced to restrain the freedom of expression enjoyed by the former theologians. This process clearly began with Augustine's book De Trinitate, but it reached its peak in the work of scholastic thinkers at schools and universities (e.g. in the Sententiae of Peter Lombard). Latomus listed the most important merits of the scholastic theologians as follows: they presented "the divine things" (1) in their proper place within a fixed structure, (2) in an exhaustive and non-fragmentary fashion, and (3) with accurate theological-technical formulations. (4) The presentation was dogmatically sound and in accordance with the Church's determinations; any ambiguity or hint of error, as could still be found in the Fathers' writings, was removed. (5) Thanks to their knowledge of dialectics and Aristotelian philosophy, scholastics were also provided with the instruments for creating an impressive apology of Christian faith, in discussion with pagan philosophers and heretics. ${ }^{84}$ In Latomus's view, scholasticism was the most adequate reflection of the oratio mentalis of the first revelation, and hence, had a normative function. Of course, it was the role of the magisterium of the Church, the pope and the General Councils, to recognize the scholastics' writings as trustworthy or truthful, on the basis of the lex evangelica handed down in the Church. 85

Apart from this scholastic theology, which was also called the "subtle" or "spiritual" theology, Latomus recognized another way of theological practice. It was the "rude, corporal, common or popular theology" 86 which was directed towards the preaching and explanation of the gospel to the illiterate masses. Future preachers could apply themselves to grammar and languages, to rhetoric and poetics - or in short: to the bonae literae - in order to touch the hearts of their audience. This corporal theology, which Latomus seems 
to identify with biblical theology, could be found among the Church Fathers before Augustine. Humanists likely wanted to restore that kind of theological practice. However, Latomus expressed reservations about Origen in particular, the great favourite of the humanists. He warned his readers that they "... while innocently emulating the splendour of his style and his learning, drink in poisonous doctrines." ${ }^{87}$ Latomus, for his part, defended unswervingly the priority of the "spiritual" or "speculative" theology.

As a consequence, students had to begin their exploration of the "divine secrets" with a thorough introduction to scholastic theology. With the help of a scholastic guide, they could then indeed go back into the tradition and interpret Scripture and the Church Fathers according to the doctrine of faith. ${ }^{8} 8$ From the outset of their theological education, students also had to read the text of the Bible and, at a later stage, even memorize parts of it, beginning with the New Testament. The Latin Vulgate evidently sufficed. When a student ran up against difficulties, he had to make an appeal to theological commentaries and glosses rather than torment himself with a study of the original text on the basis of biblical languages. ${ }^{89}$

Dialectics and Aristotelian philosophy, however, were the most important auxiliary sciences of scholastic theology. Hence, they had to occupy the most prominent place in the curriculum of the arts faculty. The term "philosophy” was taken to mean: natural philosophy, mathematics (principally arithmetic), moral philosophy, and certainly also metaphysics. ${ }^{90}$ First, with the help of natural philosophy, i.e. the knowledge of the natural things in creation, people could ascend to the Creator himself. ${ }^{91}$ Further, with the support of philosophy and logic, theologians were able to deduce the doctrine of the Church on the basis of Scripture, the Fathers, and the whole Tradition. The philosophical apparatus was well designed to define theological concepts clearly, and to indicate the logical connections and the distinctions between them. As indicated, it was also philosophy that had to provide the instruments for a fitting apology of Christian faith, in dialogue with pagan philosophers and "heretics."

Latomus admitted that some scholastics tediously dwelled upon certain superfluous issues, and he agreed that abuses would be better banished. ${ }^{92}$ On the other hand, he argued that some items which humanists considered as meaningless were nevertheless useful in order to grasp the content of doctrine clearly. This was the case, for instance, with the discussion of whether the divine nature of Christ remained linked to his dead body in the grave or to his soul that had descended to hell, or to both. ${ }^{93}$ Criticism on far-fetched scholastic controversies was, however, not applicable to Louvain theological practice. Even Erasmus, who was generally critical of the magistri 
Lovanienses, was forced to recognize that they practised scholastic theology in a reserved, moderate fashion. ${ }^{94}$

Latomus also responded to the humanists' view that piety was a condition for understanding the Scripture and, hence, for being a good theologian. ${ }^{95}$ It was Petrus who, in the first part of the Dialogus, had already defended this opinion. Latomus, a skilful dialectician, took the opportunity to develop, in a more general way, his ideas regarding the relation between piety, the study of Scripture, and theology. He argued that the study of Scripture was useless both for the pious and for the theologians. As for the pious, they had already reached the life of faith, hope, and love, and hence they did not need the help of Scripture anymore, except to instruct others. As for the (speculative) theologians, they did not have as their first objective the study of the Bible, its language and figures of speech. It was expected that a theologian should show an initial inclination towards piety; yet it was not necessary for him to live a life of perfect piety, to burn for spiritual love, or be entranced. The "holy rusticity," i.e. the quiet, simple day-to-day life, was just as important, as stated by Jerome. The theologian must be aware, however, that piety was the ultimate objective of theology. According to Latomus, this was comparable to medicine - of which the ultimate goal was people's health, while it was not necessary for the physician himself to have perfect health. ${ }^{96}$ In Latomus's view, real piety meant membership in the Church and submission to its doctrine, which contained the real sense of Scripture. The opponents of the pious were, according to Latomus, the heretics who obstinately rejected the doctrines taught by the Church.

Knowledge of languages, like piety, was by no means necessary in the training of future theologians, although Latomus surely would not want to go so far as to condemn people who aimed at acquiring a knowledge of languages (to relegate himself thereby to the historical examples, Jerome, Pico, and Mithridates, also quoted by Mosellanus). ${ }^{97}$ In the first part of his Dialogus, Latomus had already entered into a direct debate with Mosellanus and tried to refute the humanist arguments in favour of language study. Latomus's mouthpiece, Johannes, firstly tried to reduce the authority of the Decretum Gratiani. ${ }^{98}$ He argued that no pope or General Council had ever accepted the Decretum Gratiani as an official book of canon law. In his view, it was merely a private collection in which the authority of each canon relied upon the author, i.e., the Church Father from whom it had been derived. Latomus supposed that the author of the canon Ut veterum was either Augustine or Jerome, as he seemed to assume more specifically in other passages of his work. ${ }^{99}$ Latomus must have known, however, that in ecclesiastical practice the Decretum Gratiani was in fact used as a book of canon law on the basis of 
which popes and bishops had built their legislation. The reasoning according to which Johannes on the one hand tried to minimize the scope of the canon Ut veterum, but on the other hand accepted that it was possibly originating from Augustine or-more correctly-from Jerome, sounds rather bizarre. Whereas on most occasions the authority of Augustine was highly esteemed by Latomus, here it was minimized. It confirms the picture that, during the controversy, the Church Fathers were simply used to underpin whichever position one wanted to defend. In this case, Latomus aimed to prove that a collation of the Latin text of the New Testament with the "original" Hebrew or Greek text offered no certainty about the content of the gospel message.

The decree Inter sollicitudines was not a convincing incentive for a theologian to take up the study of the languages either. The Louvain theologian rightly stated that the decree Pope Clement V had issued in the wake of the Council of Vienne was not directed towards the study of biblical languages, but towards the study of Hebrew, Arabic, and Chaldean (Aramaic), which could be used in missionary work among Jews and Muslims. ${ }^{100}$

Johannes also replied to some of Mosellanus's biblical arguments. He first referred to the rather peculiar reasoning according to which the three languages - Latin, Greek, and Hebrew - had been inscribed at the top of Jesus's cross and therefore had been sanctified by his blood. A sophist might remark that as these inscriptions had been located at the very top of the cross, they would never have been touched by Jesus' blood, and thus they were not sanctified. Moreover, as Johannes continued somewhat ironically, on the basis of similar reasoning one could argue that the lance, which had pierced Jesus's heart and had undoubtedly been touched by his sacred blood, sanctified the conduct of war. ${ }^{101}$

Petrus, for his part, confirmed Mosellanus's statement that God had tied his wisdom and his law to certain letters or even the jots and tittles of a particular language, for Christ has said "Not one jot or tittle will pass..." (Mt. 5:18). Johannes forced him to accept the consequences of this reasoning: that he who knows the language can see the hidden wisdom of God and he who does not know it cannot see it. Johannes retorted, however, by asking why the Pharisees and other Jews who definitely knew the Hebrew tongue could still misunderstand the law and the prophets. ${ }^{102}$ Erika Rummel argues that Mosellanus indeed confirmed that the knowledge of biblical languages was necessary to understand Scripture, but she rightly doubts whether Mosellanus would have said that this knowledge was a sufficient condition to understand God's Word, as Johannes implies. ${ }^{103}$

It was particularly in the first book of the Dialogus that Latomus replied to Mosellanus's biblical arguments. In the second book, however, we read 
Latomus's interpretation of 1 Corinthians $12-14$, a passage that played an important role in Mosellanus's biblical argumentation. In Latomus's view, Paul had explained unequivocally to the Corinthians that there was in fact a hierarchy in the gifts of the Spirit. The gift of tongues was by no means the most valuable. More important than the ability to speak in tongues was the ability to interpret what was expressed, because it was only in this way that the Church might receive edification. Both speaking in tongues and the explanation of what has been spoken, however, were yet surpassed by the gift of prophecy and the word of knowledge. Latomus's senex had drawn the conclusion that tongues and languages by no means sufficed for interpreting the res divinae. ${ }^{104}$

The next point in the dialogue was also a retort to Mosellanus, who complained in his Oratio that God's realm, which was to encompass all nations, was diminished by the restricted knowledge of languages and the reliance on Aristotelian philosophy and dialectics. Latomus, for his part, stated that those "who attribute the shamefully reduced confines of the Christian realm to neglect of languages, err. They use a sophism to establish a causal relationship where there is none. It is avarice, luxury, ambition, and strife that are truly to blame [for this state.]"105

The debate between humanists and scholastic theologians concentrated particularly on the interpretation of what the Church Fathers actually proposed in the area of language study and scriptural theology. With a reference to Jerome and particularly to Augustine's De doctrina Christiana, the humanists' mouthpiece Petrus emphasized that it was necessary for a theologian to know the biblical languages because the Gospel of Matthew was written in Hebrew and the rest of the New Testament in Greek. The (Latin) text was corrupted due to errors of a translator, an alleged emendator, or an ignorant or sleepy copyist. The emendation of the text required the knowledge of the original languages. ${ }^{106}$ However, Latomus replied that the Greek and Hebrew texts were also corrupted in the course of an age-long tradition. Latomus even held on to the prejudice that Greeks and Jews had deliberately falsified the text in order to adapt it to their theological presuppositions and to justify their positions in polemics with Latin Christians. ${ }^{107}$ He was not opposed in principle to a consultation of the Hebrew and Greek "original” with a view to the emendation of the Latin codices, as the Church Fathers Augustine and Jerome requested; yet he argued that this method was not an infallible means to recover the original truth of the gospel and that the Latin Vulgate in several of its passages rendered the original revelation better than the so-called Greek (or Hebrew) source text did. ${ }^{108}$ 
Latomus endorsed the humanists' argument that the idiomatic particularities, figures of speech, and nuances of the original language could not correctly be rendered by a translation. ${ }^{109}$ But he added immediately that this was not the issue; that a faithful translation was not actually possible. Latomus's fundamental answer to this and other arguments was that theologians had to concentrate in the first place on the content of divine truth (res divinae) and not on the language (verba) in which it was rendered. Translations were appropriate to disclose the res as doctrinal content. ${ }^{110}$ The Latin Vulgate, complete with theological commentaries and glosses, could reflect the doctrine more than adequately. If necessary, theologians could seek advice from specialists in Greek, Hebrew, or Chaldean (Aramaic). ${ }^{111}$

According to Latomus, this was the key to interpreting the famous passage in De doctrina Christiana in which Augustine stated that knowledge of the biblical languages Hebrew and Greek was necessary to render the Scriptures intelligible. ${ }^{112}$ Rummel rightly states that Latomus's mouthpiece Johannes “dissect[s] Augustine's words on the subject of language studies, skillfully quoting snatches from his work to support his own views and passing over others that do not serve his purpose."113 Latomus argued that Augustine had meant that the study of the languages and hence the original text of Scripture ("divinae scripturae") was quite necessary for those who applied themselves to corporal theology, but not for those who occupied themselves with speculative theology. The latter consecrated themselves to the "divine things" ("res divinae") as such and it was irrelevant whether or not they could read the Bible in its original language. ${ }^{114}$ Furthermore, in Augustine's time there was a need to appeal to the Greek or Hebrew original due to the troubling variety of Latin versions of very unequal quality. However, Latomus argued that the Church of the sixteenth century (in contrast to the Church of Augustine) used only one generally accepted and authorized Latin Bible, which was the Vulgate. To Latomus, this was proof enough that the Vulgate was an adequate translation; that in the Vulgate, the original truth of the faith was better rendered than in any other version. ${ }^{115}$ Latomus also repeated that the so-called corruption or ambiguity of the Latin text was often due to a lack of clarity in the "original” Hebrew or Greek text. Hence, a reference to this source text was useless. To underpin his statement, Latomus could easily find support in Augustine's De doctrina Christiana. ${ }^{116}$ Latomus emphasized that even Augustine had suggested three alternative possibilities: (1) a theologian could appeal to specialists in Hebrew or Greek when he experienced some difficulties; (2) he could study languages himself; or (3) he could compare several (Latin) translations in order to emend a doubtful passage. ${ }^{117}$ Furthermore, as an implicit answer to Mosellanus, Latomus admitted that 
Origen could be praised because he had studied Hebrew, notwithstanding his relatively advanced age. Jerome could rightly be admired for his knowledge of languages also. Augustine for his part had never learned Hebrew and yet he still managed to produce the most sublime biblical commentaries, e.g. on Genesis and on Psalms. ${ }^{118}$ In Latomus's eyes, the study of languages was thus not a prerequisite for a good theologian.

Latomus followed the same line of thought when answering the question about whether the study of rhetoric was necessary for a theologian. He stated that the persons who showed an aptitude for an active, pastoral life could apply themselves to the study of biblical theology and its auxiliary sciences: rhetoric and literature. From rhetoricians and poets one could learn how to use parables, similitudes, and general wisdom in preaching. However, the one who was talented in abstract reasoning should apply himself to the study, not of rhetoric and literature, but rather of speculative theology and its auxiliary sciences, dialectics and philosophy. The one who showed an aptitude for both pastoral activity and abstract reasoning had to concentrate on speculative theology. If this person had attained a sufficient level of wisdom and insight, the eloquence and fluency of expression would follow automatically. ${ }^{119}$ To ground this statement, Latomus referred to some passages carefully chosen from the fourth book of Augustine's De doctrina Christiana, ${ }^{120}$ concealing the fact that the whole book is devoted precisely to the benefit of rhetoric!

Latomus also referred to the pagan authors of classical antiquity whom Mosellanus had presented to the students in order to prompt them to the study of Greek. Upon closer examination of the content of the literature, Latomus's senex approved of rhetoric and poetry insofar as these were in accordance with the Christian faith. At the same time, he warned that Greek poets such as Homer, Lucian, and Marullus seldom offered literature of an edifying ilk, which rendered it unsuitable for young Christians. In guarded terms, the senex gave his approval to Virgil's writings. ${ }^{121}$

As an interesting conclusion to his arguments, Latomus's mouthpiece Johannes examined the reproach that dialectically skilled theologians would be sophists. This might be the case, he argues, but every science could be practised in a good way (with an aim to the right goal) and in a bad way (only in and of itself). Jurisprudence, medicine, and rhetoric counted both sophists and true professionals among their practitioners. Among theologians, Latomus considered two kinds of sophists. Firstly, there were speculative theologians who dealt with superfluous questions and neglected the study of Scripture. Secondly, there were biblical theologians who attached excessive interest to language studies, rhetoric, and poetics, and who disapproved of 
dialectical argumentation, "barbarous Latin," doctrines, laws, canons, decretals against schismatics, etc. ${ }^{122}$ Rummel states that this part of the work is particularly characterized by a "bitter antagonism" and "shrill accusation," and that it is filled with quotations taken from Erasmus's writings. There can be no doubt that the work was also a harsh retort to the great humanist of Rotterdam.... 123

\section{Conclusion: ad divinarum scripturarum or rerum cognitionem?}

The controversy between Latomus and and the biblical humanists Mosellanus and Erasmus was a classic example of the sixteenth century scholastichumanist debate. At stake were the ways in which theology ought to be practised, thus enabling theologians to get in touch with God and "divine things." Mosellanus argued that people could come closer to the mystery of God by the study of the "divine Scriptures" through a sound knowledge of Greek (and Hebrew), along with classical Latin. According to Latomus, however, it was with the help of the scholastics, and auxiliary sciences, dialectics, and Aristotelian philosophy, that theologians could arrive at knowledge of "divine things." 124 What is striking is that both Mosellanus and Latomus elaborated the semantic and epistemological backgrounds of their respective positions. Mosellanus was convinced that concrete words and texts, by expressing concepts, offered unmediated access to knowledge of the (divine) real. He was not inclined to let an abstract concept, disconnected from a concrete spoken language, function as an essential intermediary between word and reality. In the view of Latomus and his colleagues, Mosellanus attached too much value to the elegant expression of words per se, as if words provided immediate access to reality. The objects of reality were first signified by abstract concepts in the observer's mind and only later expressed by concrete words. The accurate technical language used by scholastics was considered to be the most appropriate medium through which the conceptual understanding of (divine) reality was expressed. I must emphasize, however, that Latomus and his colleagues were not as conservative as they are sometimes depicted in scholarly literature. The Louvain theologians remained fundamentally open to the study of the languages and, in the course of the following years and decades, they would gradually accept the study of Scripture as a valid constituent of theological studies. ${ }^{125}$

Katholieke Universiteit Leuven 
Notes

* I want to thank William 'Wolf' Diedrich for the valuable assistance in translating this text.

1. See also Wim François, "The Plea by the Humanist Petrus Mosellanus for a Knowledge of the three Biblical Languages. A Louvain Perspective," Revue d'Histoire Ecclésiastique 98 (2003), pp. 438-81.

2. The standard work on Latomus remains: Marcel Gielis, Scholastiek en Humanisme. De kritiek van de Leuvense theoloog Jacobus Latomus op de Erasmiaanse theologiehervorming (Tilburg: Tilburg University Press, 1994). The spirit and thrust of this doctoral dissertation has been summarized in Gielis, "L'augustinisme anti-érasmien des premiers controversistes de Louvain Jacques Latomus et Jean Driedo,” L'Augustinisme à l'ancienne Faculté de théologie de Louvain, ed. Mathijs Lamberigts and Leo Kenis (Leuven: Leuven University Press, Peeters, 1994), pp. 19-61, esp. pp. 19-32.

3. Erika Rummel, Erasmus and his Catholic Critics, 2 vols. (Nieuwkoop: De Graaf, 1989), vol. 1, pp. 72-87.

4. The standard work for Mosellanus's biography remains: Oswald G. Schmidt, Petrus Mosellanus. Ein Beitrag zur Geschichte des Humanismus in Sachsen (Leipzig: Fleischer, 1867). An outline of his life also in: Michael Erbe, "Petrus Mosellanus," Contemporaries of Erasmus. A Biographical Register of the Renaissance and Reformation, ed. Peter G. Bietenholz and Thomas B. Deutscher, 3 vols. (Toronto: University of Toronto Press, 1985-87), vol. 2, pp. 466-67; Heinrich Grimm, “Mosellanus (eigtl. Schade), Petrus,” Neue Deutsche Biographie 18 (1997), pp. 170-71; Peter Walter, "Mosellanus (eigtl. Schade), Petrus,” Lexikon für Theologie und Kirche 7 (1998), p. 495; Achim Krümmel, "Mosellanus, Petrus,” Biographisch-Bibliographisches Kirchenlexikon 6 (1993), pp. 169-171 and <http://www.bautz.de/bbkl/m/mosellanus.shtml> (access 08.07.2005). Considerable biographical information can be found also in: Max Steinmetz, "Die Universität Leipzig und der Humanismus," Alma Mater Lipsiensis. Geschichte der Karl-Marx-Universität Leipzig, ed. Lothar Rathmann (Leipzig: Ed. Leipzig, 1984), pp. 33-54, esp. 51-54; Henry de Vocht, History of the Foundation and the Rise of the Collegium Trilingue Lovaniense 1517-1550, 4 vols. (Leuven: Bibliothèque de l’Université, 1951-55), vol. 1, pp. 306-8; Reinhold Weier, "Die Rede des Petrus Mosellanus, Uber die rechte Weise, theologisch zu disputieren',” Trierer Theologische Zeitschrift 83 (1974), pp. 232-45; Ulrich M. Kremer, "Mosellanus: Humanist zwischen Kirche und Reformation," Archiv für Reformationsgeschichte 73 (1982), pp. 20-34; Kremer, "Petrus Mosellanus und Julius Pflug. Ein Beitrag zur Geschichte des Einflusses von Erasmus in Sachsen,” Pflugiana. Studien über Julius Pflug (1499-1564). Ein internationales Symposium, ed. Elmar Neuss and Jacques V. Pollet (Münster: Aschendorff, 1990), pp. 3-22; François, pp. 440-45.

5. What is not so clear is the chronology of Mosellanus's departure from Cologne, his (possible) first stay in Leipzig, his move to Freiburg, and, assuming that he had stayed in Leipzig previously, his return to the city. Compare with Schmidt, pp. 16-18; Krümmel, p. 169.

6. On humanism at Leipzig University, see Steinmetz, pp. 33-54; Konrad Krause, Alma mater Lipsiensis. Geschichte der Universität Leipzig von 1409 bis zur Gegenwart (Leipzig: Leipziger Universitätsverlag, 2003), pp. 42-51. 
7. For a discussion of this opening speech, see in particular Weier; Erika Rummel, “Argumentis, non Contumeliis: The Humanistic Model for Religious Debate and Erasmus' Apologetic Letters," Self-Presentation and Social Identification. The Rhetoric and Pragmatics of Letter Writing in Early Modern Times, ed. Toon Van Houdt, Jan Papy, Gilbert Tournoy, and Constant Matheeussen (Leuven: Leuven University Press, 2002), pp. 305-15; Kremer, "Mosellanus: Humanist,” pp. 29-33; and Heiko A. Oberman, Luther: Mensch zwischen Gott und Teufel (Berlin: Severin und Siedler, 1982), pp. 338-40.

8. Martin Luther to an anonymous reader in Leipzig, 28 May 1522, ed. Gustav Bebermeyer and Otto Clemen, WABr, 2 (Weimar: Hermann Böhlaus Nachfolger, 1931), nr. 499, p. 544-45 1. 7: "De praedestinatione sentire Mosellanum cum Erasmo antea novi; totus enim Erasmianus est;” 1. 31-35: “Salutabis autem Mosellanum. Neque ideo alienus sum ab eo, quod Erasmi magis quam mea sectatur. Imo dicito ei, ut sit fortiter Erasmianus. Erit tempus, cum aliter sentiet. Interim et ferendus optimi amici sensus infirmior.”

9. For an overview of Mosellanus’s publications, see Schmidt, pp. 85-87. Also: Krümmel, p. 170 and Grimm, p. 171.

10. About "Kollegiaturen,” prebendaries, and other privileges at the University of Leipzig, see Siegfried Hoyer, “Die scholastische Universität bis 1490,” Alma Mater Lipsiensis, ed. Rathmann, pp. 15-16; Steinmetz, pp. 33-39; and Krause, pp. 27-31.

11. This information is given only in: Kremer, "Mosellanus und Pflug,” p. 18.

12. A number of sources give the date of death as February 17th, others as April 19th. Schmidt assesses the latter date to be the most reliable (Schmidt, p. 75). Kremer gives April 18th as the date of passing, which apparently is also carried in a number of sources (Kremer, “Mosellanus und Pflug,” p. 18).

13. I am following the editio princeps: Petrus Mosellanus, Oratio de variarum linguarum cognitione paranda Petro Mosellano protegense avthore Lipsiae in magna ervditorvm corona pronvnciata/Lipsiae: in officina valentini Schvmann, 1518, 24 f.; in $4^{\circ}$. For an analysis of Mosellanus's Oratio, see also De oudste Roomsche bestrijders van Luther, ed. Frederik Pijper, Bibliotheca Reformatoria Neerlandica, 3 ('s-Gravenhage: Nijhoff, 1905), pp. 13-18; de Vocht, vol. 1, pp. 308-311; Charles Béné, "Saint Augustin dans la Controverse sur les trois langues à Louvain en 1518 et 1519,” in Colloquium Erasmianum. Actes du Colloque International réuni à Mons du 26 au 29 octobre 1967 à l'occasion du cinquième centenaire de la naissance d'Érasme (Mons: Centre universitaire de l'État, 1968), pp. 19-32; Béné, Érasme et Saint Augustin ou influence de Saint Augustin sur l'humanisme d'Érasme (Genève: Droz, 1969), pp. 285-88; André Godin, Érasme lecteur d'Origène (Genève: Droz, 1982), pp. 215-20; Rummel, Erasmus and his Catholic Critics, vol. 1, pp. 68-72; François, pp. 445-69. Scattered information to be found also in: Weier; Kremer, "Mosellanus: Humanist;" and particularly in Kremer, "Mosellanus und Pflug."

14. Mosellanus, f. Aiij r: "Nimirum quod citra harum [linguarum] praesidium arcanae illae literae, nobis partim hebraice a prophetis, partim graece ab apostolis relictae pro dignitate tractari nullo modo quaeant;” f. Bvi r: “... nullam esse literariam professionem, quae non cum ex aliarum linguarum, tum vero maxime grecae \& hebraicae cognitione lucem accipiat... Ac primum quidem in disciplinarum omnium regina Theologiae...”

15. Mosellanus, f. Bvi v. 
16. Mosellanus, f. Aij v: "Et quum hinc non nisi pacem, \& $\tau \alpha \pi \varepsilon ı v o \varphi \rho o \sigma v ́ v \eta v$ [ta peinophrosunein] inuenirent, rixandi artificium aliunde inuexerunt, et mansuetissimam illam Christi IESV agni patientissimi doctrinam, quantumuis repugnantem, ad Dialectices, \& mortaleis sapientiae leges obtorto, quod aiunt, collo pertraxerunt.” A possible allusion to Augustinus, Ep. LIV. Ad Ianuario 5, ed. Klaus D. Daur, CCSL, 31 (Turnhout: Brepols, 2004), p. 230 l. 104-105 and Augustinus, De doctr. Christ. II, xxxi 48, ed. Joseph Martin, CCSL, 32 (Turnhout: Brepols, 1962), pp. 65 l. 5 - 66 l. 7. Further: Mosellanus, f. Bvi $\mathrm{r}-\mathrm{v}$ : "Principio quis ignorat verae theologiae officium, si non solum, summum certe \& dignissimum carnalibus affectibus ante velut sub iugum missis, ac mente si liceat per inferiores disciplinas praepurgata, beati illius viri exemplo, non in Aristotelis metaphysicis, non Platonis Ideis non Scoti quodlibetis, sed de lege die nocteque meditari... Hae sunt scripturae, ad quas scrutandas nos omneis ipse mittit Christus...” An allusion to Ps 1:1-2 [VUL]: "Beatus vir... in lege eius meditabitur die ac nocte.” Also: Mosellanus, f. Bvi $\mathrm{v}$ : "Porro qua via rerum signa verba scilicet peruestigabis, si linguarum quibus vetus ac nouum instrumentum est conscriptum, omnino fueris imperitus?"

17. In the preface to the Gospels, Jerome had already pointed out the breaking up into several "rivuli" of the textual transmission of the New Testament: "Hoc certe cum in nostro sermone discordat et diversos rivulorum tramites ducit unio, de fonte quaerendum est” (Hieronymus, "Praefatio in Evangelio," Biblia sacra iuxta vulgatam versionem, ed. Bonifatius Fisher, Robert Weber, and Roger Gryson, 4th ed. [1969; Stuttgart: Deutsche Bibelgeselschaft, 1994; repr. 2003], p. 1515, 1l. 22-23). The motif to leave the streamlets of diverse Latin Bible interpretations and to return to the clear spring, which is the "original” Hebrew and Greek Bible, is also to be found in, among others, Hieronymus, Commentarii in Zachariam II, viii, ed. Marc Adriaen, CCSL, 76A (Turnhout: Brepols, 1970), p. 820 1. 526-527; Ep. XX. Ad Damasum 2, ed. Isodorus Hilberg, CSEL, $54^{2}$ (Wien: Verl. der Österreichischen Akademie der Wissenschaften, 1996), pp. 104 l. 14 - 105 l. 6; Ep. XXVII. Ad Marcellam 1, CSEL, 542, p. 224 1. 10-15; Ep. XXVIII. Ad Marcellam 5, CSEL, 54², p. 229 l. 15-18; Ep. CVI. Ad Sunniam et Fretelam de Psalterio 2, ed. Isodorus Hilberg, CSEL, $55^{2}$ (Wien: Verl. der Österreichischen Akademie der Wissenschaften, 1996), p. 249 l. 4-9.

18. Mosellanus, f. Aij r: “... quia graecam linguam discere, aut temporum iniuria non poterant, aut per ignauiam nolebant, omissis graecorum fontibus in turbidis ineptissimarum translationum riuulis, vel etiam qualiscunque nebulonis somniis miseri consenuerunt;” $f$. Dvi v: "Certe in omnibus hiis, qui posthabitis graecorum fontibus vbi abunde proluere labra licebat, in arescentibus latinorum riuulis vix sitim restingunt..."

19. Mosellanus possibly borrowed the motif-that God knew the languages of all peoples who prayed to Him - from Origenes, Contra Celsum VIII.37, ed. Marcel Borret, SC, 150 (Paris: Cerf, 1969), pp. 256-57. The motif that angels and saints are the mediators between man and God, and offer men's prayers to the Lord, had perhaps been taken

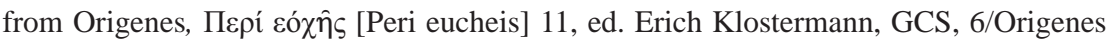
Werke, 3 (Leipzig: J.C. Hinrichs, 1901), pp. 321-25; possibly also Origenes, HomLev. IX, 8, ed. Marcel Borret, SC, 287 (Paris: Cerf, 1981), pp. 107-13. It is uncertain however whether Mosellanus knew of the decision of the Synod of Frankfurt (794) and the treatise De vocatione gentium which was also translated into German, probably in the wake of the synod. The synod and the treatise both stated that a person could pray to God in any language and that the Lord perfectly understood these prayers. See Julius Schwering, “Die Idee der drei heiligen Sprachen im Mittelalter,” Festschrift August Sauer. Zum 70. 
Geburtstag des Gelehrten am 12.Oktober 1925, ed. René Backmann (Stuttgart: Metzler, 1925), pp. 3-11, esp. 5-6.

20. A lot of early modern writers emphasized the uniqueness of the human capacity for reason and language and the brutishness of the brute beasts. In this they also followed ancient authorities: Aristoteles, The Politics of Aristotle, 1.2, 1253a 9-10, ed. William L. Newman, 4 vols., (1887; rpt. New York: Arno Press, 1973), vol. 2, p. 3; Cicero, De Oratore I.viii.31, 33, ed. E.W. Sutton and H. Rackham, Loeb, 348 (Cambridge, MA: Harvard University, 1988), pp. 22-25; Cicero, De Inventione I.iv.5, ed. H.M. Hubbell, Loeb 386 (London: Heinemann, 1968), pp. 12-13.

21. For this argument, see Mosellanus, ff. Bi v - Biij v, inter alia f. Bij v: "Huc viri optimi huc tendunt, vt intelligant hanc siue orationis siue rationis facultatem, quantumuis sit in nobis diuinae na[t]urae index, quantumuis vtilis, vires tamen suas, \& opes non nisi per linguarum cognitionem explicare posse” and particularly the summary of this line of argument in f. Biij v: "Ergo si omnium gentium linguas non solum nouit deus, sed \& deo proximi angeli, nec idem negatur in diuis, manifestum euadit \& homines, si variarum linguarum cognitionem teneant, dei imaginem propius referre, \& ad caelitum dignitatem proxime accedere...”

22. Mosellanus, ff. Aij v - Aiij r. Mosellanus most likely has been inspired by Hieronymus, Ep. LX. Ad Heliodorum Epitaphium Nepotiani 4, CSEL, 54², p. 553 l. 1-4. The oldest record of this argument seems to be found in Hilarius Pictaviensis, Tractatus super psalmos. Instructio psalmorum 13,15, ed. Anton Zingerle, CSEL, 22 (Wien: Tempsky, 1891), p. 13 l. 16-19. Also in Augustinus, Enarr. in Ps. LVIII, 1.1, ed. Eligius Dekkers, CCSL, 39 (Turnhout: Brepols, 1956), pp. 729 l. 9 - 7301.12 and Augustinus, Tract. in Ioh. CXVII, 4, ed. Radbodus Willems, CCSL, 36 (Turnhout: Brepols, 1954), p. 653 1. 6-10. For this matter, see Schwering, pp. 4-6, 8-10; Robert E. McNally, “The 'tres linguae sacrae' in Early Irish Bible Exegesis,” Theological Studies 19 (1958), pp. 395-404, esp. 395-96.

23. 1 Co $12: 10.28-30$.

24. 1 Tim 1:6; 4:7; 6:3-5; 2 Tim 2:16.

25. Act. 2:1-13.

26. Mosellanus, ff. Biiij $r$ - Bvi $r$, with a summary of this second line of argument in $f$. Bvi r: “... sufficere possent, quae supra iam diximus, vnicum verae theologiae doctorem spiritum, linguarum specie in theologorum principes apostolos descendisse, tum Paulum diuinorum mysteriorum interpretem, \& ipsius dei velut consiliarium tanti facere linguarum cognitionem, vt non solum non prohibeat, sed si quis recte vtatur, vel prophetiae muneri praeponat." We even find a summary of the first and the second series of arguments in Mosellanus, f. Bv r: "Proinde si per linguarum cognitionem orationis facultas latius patet, si diuinitatis et angelorum est linguas scire, si idem diuorum, si denique sanctissimis hominibus citra omnem humanam operam spiritus sancti afflatu contigit, si a sanctissimo Paulo tantopere laudatur, quid restat, cur non, si ad caelitum dignitatem accedere, et dei imaginem ad quam creati sumus, propius referre est cordi rem tam diuinam, tam laudatam vno consensa [=consensu] amplectamus [=amplectamur] omnes?” See also f. Eiij r.

27. Mosellanus, f. Cii r-v.

28. Mosellanus, f. Bvi v. 
29. Mosellanus, ff. Civ r; Diij v: "Doctissimus ille Origenes, Sanctissimus Hieronymus, quamquam iam decies fere veteris instrumenti libris in latinum sermonem conuersis, ad synceriorem tamen theologiae cognitionem, ille senex, hic iuuenis maturus hebraeorum alphabetum discere nec erubuerunt viri tanti, nec desperauerunt natu grandes...” In the literature available, the question is discussed which Church Father was actually Mosellanus’s great favourite. See Béné, “Érasme et saint Augustin,” p. 285; Godin, p. 216; Kremer, "Mosellanus: Humanist,” p. 30; Kremer, "Mosellanus und Pflug,” pp. 11-12. See also François, p. 447.

30. Mosellanus, ff. Bvi v - Ci r and f. Eii v. The tradition according to which Origen had already reached an advanced age when he started studying Hebrew, and undertook his critical work of the Septuagint, is found in Hieronymus, De viris illustribus 54, 6-7, ed. Aldo Ceresa-Gastaldo, Biblia Patristica 12 (Firenze: Nardini, 1988), p. 154.

31. Mosellanus, f. Ci r.

32. Mosellanus, ff. Ci r - Ciii v. The precise ending of the prosopopoeia is not very clear.

33. See inter alia Mosellanus, f. Cij r: "Vos autem ita rem temperatis immo confuditis, vt si quis vestras istas disputationes ad libram expendat, longe plus Aristotelicae philosophiae, immo spurcissimae sophistices, quam solidae scripturae sit inventurus, cum nullus interim adsit eloquentiae nitor, nulla disserendi gratia, sed omnia verborum prodigiosa barbarie et odiosis argutiis referta mire quam frigeant, et lectorem mundiciae studiosum deterreant;” f. Cij v: “Sed quia scripturae testimonia frigide tractatis, neminem acce(n)ditis, et Aristotelis Christianae fidei, si quisquam alius philosophorum, infestissimi crebrior sit mentio, quam Pauli."

34. Mosellanus, f. Ci r-v. Seems especially to be an allusion to Hieronymus, Ep. CVI. Ad Sunniam et Fretelam de Psalterio 2, CSEL, 55², p. 249 l. 4-9. See also Hieronymus, Aduersus Heluidium de Mariae uirginitate perpetua, ed. Jacques-P. Migne, PL, 23 (Paris: Vrayet de Surcy, 1845), col. 191 B.

35. Mosellanus, f. Ciii r (in the prosopopoeia). Also f. Di v. Mosellanus refers to Augustinus, De doctr. Christ. II, xi 16, CCSL 32, p. 42 1. 2-4. He further makes an allusion to Augustinus, Confessiones I, xiii 20, ed. Luc Verheijen, CCSL, 27 (Turnhout: Brepols, 1981), p. 11 l. 1-6 and possibly to Confessiones I, xiv 23, CCSL 27, pp. 12 l. $1-13$ l. 7. However, that Augustine in his adult years returned to the study of Greek, cannot be clearly deduced from the latter text. Several scholars have expressed doubts and nuances concerning Augustine's own assertion that the Greek language "kindled little enthusiasm in [him] when he was young." However, it has been shown that "toward the end of his life, Augustine was perfectly able to literally translate a Greek text and, afterwards, to use it with great liberty" (For the discussion, see e.g. Mathijs Lamberigts, "Augustine as translator of Greek texts. An example,” in Philohistôr. Miscellanea in honorem Caroli Laga Septuagenarii, ed. Antoon Schoors and Peter Van Deun [Leuven: Peeters, 1994], pp. 151-61, esp. 153-54).

36. Already mentioned in the dedication: Mosellanus, f. Aiij r.

37. See, among others, in the prosopopoeia of Jerome: Mosellanus, f. Ci v, and f. Civ r. For the decree Ut veterum, see Corpus Iuris Canonici, ed. Emil Freidberg, 2 vols. (Leipzig: Tauchnitz, 1879-81), vol. 1, col. 17. See too http://mdz.bib-bvb.de/digbib/gratian/ (access 27.09.05). The canon of the Decretum Gratiani was unmistakably inspired by Hieronymus, Ep. LXXI. Ad Lucinum Baeticum 5, CSEL, 55², p. 6 l. 11-13. 
38. In the dedication: Mosellanus, f. Aiiij r. Also in the prosopopoeia of Jerome: Mosellanus, f. Ci v. Further, Mosellanus, f. Civ r.

39. It was at the behest of the Dominican Order, and particularly under the influence of Raimon Lull, that the Council of Vienne took this decision. For the text of the decree Inter sollicitudines that Clement V promulgated in the wake of the Council, see Giuseppe Alberigo, ed., Les Conciles Oecuméniques. Les Décrets, trans. André Duval, 2 vols. (Paris: Cerf, 1994), vol. 1, pp. 784 l. 29-785 1. 5. Clement V’s decrees were incorporated into the Constitutiones Clementinae that Pope John XXII (1316-1334) issued on 25 October 1317. They were incorporated into the Corpus Iuris Canonici. On the said decree Inter sollicitudines, see Corpus Iuris Canonici, vol. 2, col. 1179.

40. In the prosopopoeia, Jerome brought Erasmus onto the scene: Mosellanus, f. Ciii r-v.

41. This was a reference to the monk who had taken offence to the fact that Erasmus had trans-

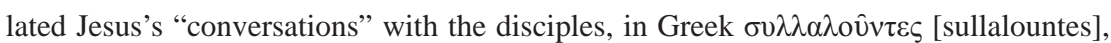
with the Latin "confabulantes" in place of a usual derivative of "colloqui." This monk had not hesitated to declare publicly that in Erasmus's eyes the gospels were evidently nothing more than old wives' tales ("fabula anilis"). A thorough philological knowledge would nonetheless have taught the monk in question that the Latin word "confabulare" simply meant speaking freely and openly with one another. On this see Mosellanus, f. Civ r-v; also f. Biiij v.

42. Mosellanus, ff. Ei v - Eiij r.

43. Mosellanus, ff. Civ v - Di r.

44. Mosellanus, f. Aiij r - Aiiij r and f. Eiij v.

45. Mosellanus's view on the relation between things, concepts, and words was more specifically expounded in the section on the necessity of languages for the study of jurisprudence: Mosellanus, f. Dii r-v. See also François, pp. 469-77.

46. See Brian Vickers, “'Words and Things' - or 'Words, Concepts, and Things'? Rhetorical and Linguistic Categories in the Renaissance,” Res et verba in der Renaissance, ed. Eckhard Kessler and Ian Maclean (Wiesbaden: Harrassowitz, 2002), pp. 287-335. Also: Christopher Ocker, Biblical Poetics Before Humanism and Reformation (Cambridge: Cambridge University Press, 2002), pp. 187-192.

47. Mosellanus, f. Dii r: "Neque vero me fugit, quid hoc loco nobis obiici soleat, videlicet eam professionem non in verbis, sed rebus, non linguis, sed pectore sitam esse."

48. For an interesting summary of the semantic and epistemological views held in the late Middle Ages: Jan P. Beckmann, “Nominalismus,” Lexikon des Mittelalters 6 (1993), col. 1222-1227; Gielis, Scholastiek en Humanisme, pp. 147-71. Further also: Martijn Schrama, "Het laatmiddeleeuws nominalisme in de geschiedschrijving," Bijdragen: tijdschrift voor filosofie en theologie 40 (1979), pp. 403-23; Jan P. Beckmann, "Nominalismus,” Lexikon für Theologie und Kirche 7 (1998), col. 894-96.

49. Mosellanus, f. Dij v: "Et quis sanus dubitat, quin, quo vberior vocum propriarum, et per hoc rebus propinquarum suppellex nobis suppetat, eo facilius quoque sit rerum discrimina docenti quidem exprimere, discenti vero percipere? Nam cum in omni scientiarum genere iuxta philosophorum traditionem, per sensus in hoc a natura inditos e singularium rerum conditione species in animum velut quasdam summas colligamus, quas illi partim

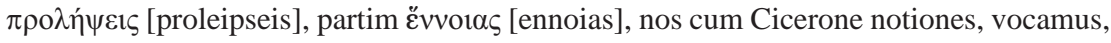


qui quaeso poterit quis hoc sine linguarum, et vocum beneficio in aureis, atque animos aliorum transfundere?” Yet, see also f. Bij v.

50. Mosellanus, f. Dij v: “... scripsit Aristoteles voces esse rerum, quae apud animum concipiantur, proxima signa. Iam mutuus est nexus, \& velut respectus sese reflectens inter signa, \& quae signantur ...” Also f. Bvi v. Mosellanus presents the spoken sounds explicitly as the "proxima signa" of concepts referring to things. He gives a very pro-

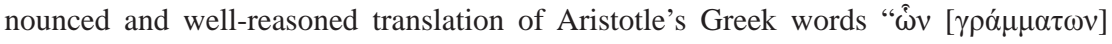

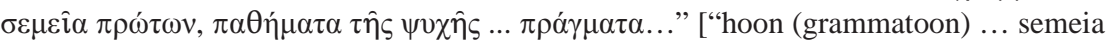
prootoon, patheimata teis psucheis ... pragmata...”] (Aristoteles, De Interpretatione, I 16a, ed. Lorenzo Minio-Paluello [1949; Oxford: Clarendon, 1966], p. 49 1. 6-7). Boethius for his part translated Aristotle's words as "voces; quorum autem hae primorum notae ... passiones animae ... res ...” (Aristoteles [latinus], De Interpretatione vel Periermenias. Translatio Boethii ..., I 16a, ed. Lorenzo Minio-Paluello [Bruges - Paris: Desclée De Brouwer, 1965], p. 5 l. 8-9). An edition of Boethius's text had been published in Leipzig some years before 1500: Aristoteles, Textus libri Perihermeneias Aristoteles/-, Lipsiae: apud Martinum Landsberg, s.d. [c. 1497-1500], 12 f; in fo. Compare with Norman Kretzmann, “Aristotle on Spoken Sound. Significant by Convention,” in Ancient Logic and its Modern Interpretations, ed. John Corcoran (Dordrecht: D. Reidel, 1974), pp. 2-21, esp. 17-18.

51. Vickers, pp. 290, 318.

52. Mosellanus, f. Dij v: “... vt, quemadmodum Ciceronem colligit Crassus, neque verba sedem habere possint, si rem subtraxeris, neque res lumen, si verba summoueris.” This is a quotation from Cicero, De Oratore III.v.19, Loeb, 348, pp. 16-17.

53. Mosellanus, f. Bvi v.

54. "Porro qua via rerum signa verba scilicet peruestigabis, si linguarum quibus vetus ac nouum instrumentum est conscriptum, omnino fueris imperitus?” (Mosellanus, f. Bvi v).

55. On Latomus's biography: Henri De Jongh, L'ancienne Faculté de Théologie de Louvain au premier siècle de son existence (1432-1540). Ses débuts, son organisation, son enseignement, sa lutte contre Érasme et Luther (Leuven: Bureaux de la Revue d'Histoire Ecclésiastique, 1911), pp. 173-80; Gilbert Tournoy, “Jacobus Latomus,” Contemporaries of Erasmus, ed. Bietenholz and Deutscher, vol. 2, pp. 304-06; Jos E. Vercruysse, "Jacobus Latomus und Martin Luther. Einführendes zu einer Kontroverse,” Gregorianum 64 (1983), pp. 515-38; Gielis, Scholastiek en Humanisme, pp. 4-5, 59-74; Gielis, "Latomus, Jacobus,” Nationaal Biografisch Woordenboek 15 (1996), pp. 425-35.

56. For the instruction in the seven artes liberales, students in Louvain could chose between four schools or paedagogia: the Lily, the Castle, the Pork, or the Falcon (de Vocht, vol. 1, pp. 63-68).

57. Gielis, Scholastiek en Humanisme, p. 70.

58. In reality, the texts were written by yet another humanist, the later reformer Wolfgang Capito. It was only in the course of the summer of 1519 that the Louvain theologians realized that they had made an incorrect assessment.

59. De Jongh, p. 200 n. 1; de Vocht, vol. 1, p. 318; Gielis, Scholastiek en Humanisme, p. 77. 
60. A general introduction to Latomus's Dialogus: Gielis, Scholastiek en Humanisme, pp. 84-95.

61. Gielis, Scholastiek en Humanisme, pp. 85-86.

62. Compare also with Erika Rummel, "Erasmus' Conflict with Latomus: Round two,” Archiv für Reformationsgeschichte 80 (1989), pp. 5-23, esp. 7, 21.

63. Martin Luther, Tischreden 463, ed. Karl Drescher, Ernst Kroker, and Oskar Brenner, WATr, 1 (Weimar: Hermann Böhlaus Nachfolger, 1912), p. 202 1. 5-7: "Unus Latomus ist der feinst scriptor contra me gewest. Et signate vobis hoc: Unus Latomus scripsit contra Lutherum; reliqui omnes, etiam Erasmus, sunt ranae coaxantes;” Tischreden 1709, ed. Drescher, Kroker, and Brenner, WATr, 2 (Weimar: Hermann Böhlaus Nachfolger, 1913), p. 189 l. 22-26; Tischreden 4119, ed. Drescher, Kroker, and Brenner, WATr, 4 (Weimar: Hermann Böhlaus Nachfolger, 1916), p. 145 l. 22-23: "Respondit Lutherus: Ille omnium antagonistarum meorum est insignis;” Tischreden 5345, ed. Drescher, Kroker, and Brenner, WATr, 5 (Weimar: Hermann Böhlaus Nachfolger, 1919), p. 75 1. 7-8: "Latomus fuit doctissimus adversariorum Lutheri; is serio scripsit.”

64. Tournoy, “Jacobus Latomus,” p. 305.

65. The text of the Dialogus has been inserted in the Opera Omnia edition of 1550: Jacobus Latomus, De trium linguarum, et studii Theologici ratione dialogus, in Opera, quae praecipue adversus horum temporum haereses eruditissime, ac singulari iudicio conscripsit .../[a Jacobo Latomo jr. et Ruardo Tapper], Lovanii: Excudebat Bartholomaeus Gravius suis impensis, Petri Phalesii, ac Martini Rotarii, 1550, ff. 157-168; in fo . I refer however to the edition in De oudste Roomsche bestrijders van Luther, ed. Pijper, pp. 41-84. For a discussion on Latomus's Dialogus, see the already mentioned standard work of Gielis, Scholastiek en Humanisme. Also: Rummel, Erasmus and his Catholic Critics, vol. 1, pp. 72-87.

66. Gielis, Scholastiek en Humanisme, pp. 144-66; Gielis, “L'augustinisme de Latomus et Driedo,” pp. 20-25. Compare with Rummel, Erasmus and his Catholic Critics, vol. 1, p. 81.

67. See among others: Latomus, Dialogus, ed. Pijper, pp. 61-64: “Tamen ne linguis nimium tribuat aliquis [senex] altius repetens dicebat, conceptus esse vocibus priores ... Addebat [senex] quod notiones significant naturaliter et sunt eaedem apud omnes, vnde sequitur quod nullius rei notio quemquam lateat. nisi quia ipsa res eius sensui, aut intellectui non sit debite oblata ... [conceptus] omni lingua pronunciari possunt.”

68. Aristoteles (latinus), De Interpretatione vel Periermenias. Translatio Boethii ..., I 16a and II, ed. Minio-Paluello, p. 5 1. 8-9 and p. 6 1. 11-13.

69. The idea of concepts as the natural signs of things, and words as conventional (i.e. learned and agreed upon) signs probably has been taken from Augustinus, De doctr. Christ. II, ii 1 - II, iv 5, CCSL 32, pp. 32 l. 1 - 34 l. 8. Compare with Ocker, pp. 32-33; Robert A. Markus, "St. Augustine on Signs," Augustine. A Collection of Critical Essays, ed. Robert A. Markus (Garden City, NY: Anchor Books, 1972), pp. 61-91; B. Darrell Jackson, “The Theory of Signs in St. Augustine’s De Doctrina Christiana,” in ibid., pp. 92-147.

70. The priority of the "verbum in corde" over the outward word, and the idea that the inner word does not belong to a particular language but is "a verbum nullius linguae," has undoubtedly been borrowed from Augustinus, De Trinitate XV, x 17 - xvi 26, ed. William J. Mountain and Frans Glorie, CCSL, 50A (Turnhout: Brepols, 1968), pp. 483 1. 1 - 501 
l. 36, and particularly De Trinitate XV, x 19, CCSL 50A, pp. 485 l. 64 - 486 l. 80; XV, xii 22, CCSL 50A, pp. 493 l. 87 - 494 l. 98; XV, xiv 24, CCSL 50A, p. 497 l. 32-39.

71. The priority of the "verbum in corde" over the outward word is also stated in Augustinus, Sermo CCLXXXVIII. In natali Joannis Baptistae. De voce et verba, ed. J.-P. Migne, PL, 38 (Paris: Migne, 1841), col. 1304-06.

72. The term "oratio mentalis" ultimately seems to be inspired by Boethius's "oratio in mente" or "vox intellectus," as distinguished from the "oratio enuntiativa," which in turn can be expressed "in voce” and "in litteris." See Anicius Manlius Severinus Boethius, In librum Aristotelis $\pi \varepsilon \rho \grave{~} \dot{\varepsilon} \rho \mu \eta v \varepsilon i ́ a \varsigma$ [peri hermeneias] (De interpretatione) editio secunda I c. 1, ed. Carolus Meiser, 2 vols., Bibliotheca scriptorum Graecorum et Romanorum Teubneriana, 1117-1118 (Leipzig: Teubner, 1877-1880), vol. 1, pp. 20 l. 9 - 21 l. 31, esp. 29

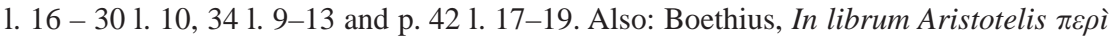

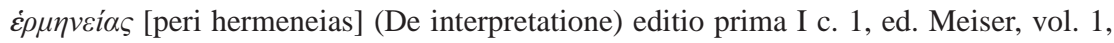
pp. 36 l. $22-41$ l. 15, esp. 38 l. 15-24.

73. The slogan "sermo rei debet esse subiectus" had been borrowed from Hilarius Pictaviensis, De Trinitate IV. 14, ed. Pieter Mulders, CCSL, 62 (Turnhout: Brepols, 1979), p. 116, 1. 27-28.

74. Latomus, p. 62: “... non sequi quod necessario rem ignoret, qui vocem nesciant ... Qui vero rem mente comprehendit, eam sermone potest exprimere, communem linguam habentibus, ... Non oportet eum qui libros eorum non legerit, aut propter linguae ignorantiam non intellexerit, res ipsas nescire. Nam potest eosdem habuisse magistros puta ipsam rerum notionem, ingenium, experientiam aut certe deum ..."

75. Compare with Gielis, Scholastiek en Humanisme, pp. 209-372; Gielis, "L’augustinisme de Latomus et Driedo,” pp. 28-32.

76. See inter alia Prov 7:3; Jer 31:33; Rom 2:15; 2 Cor 3:2-3.

77. Latomus, p. 64: “... ne hi qui eas [linguas] non habent, aut commode assequi nequeunt, rerum diuinarum desperent scientiam, Addebat senex, sibi videri quod legis euangelicae substantia nullius linguae apicibus includeretur ... primi qui in corde euangelium acceperunt, in verbis nullius linguae receperunt, in conceptibus naturaliter significantibus, qui sunt ijdem apud omnes, et omni lingua pronunciari possunt ...;” also p. 76: "primus modus diuinam legem accipiendi (quo Paulus non ab homine, neque per hominem euangelium accepit, et primi credentes, ... in cordibus eorum legem euangelicam acceperunt) sine creaturae adminiculo.”

78. Latomus, p. 67: “Crassam illam [theologiam Christus] turbis et populis tradebat incorporatam parabolis, et similitudinibus facillimis ... audientium ruditati condescendens sensim ... Subtilem vero et spiritualem seorsum discipulis ... Iuxta priorem [crassam theologiam] loquitur Paulus Corinthiis ... Iuxta secundam [spiritualem] vero inter perfectos sapientiam loquitur."

79. Latomus, pp. 64 and 76: "Lex Dei primitus in hominum cordibus digito Dei scripta est, qui eam voce interprete authoribus tradiderunt, ... Deinde eadem lex etiam mortuis chartis commissa est, per homines quos divina providentia huc destinavit.”

80. Latomus, pp. 57 and 77: "IO. Senex dicebat in primis, canoni scripturae nihil potest ecclesia addere, nihil detrahere, quia canon continet diuinitus reuelata, quae vt talia sint aut non sint, non est in potestate hominum ... Scriptura etenim sacra sua autoritatem habet 
immediate a deo, non quia Petri, aut Pauli, aut Matthaei, neque ecclesia dat ei autoritatem, sed eam quam habet autoritatem, declarat, vel monstrat.”

81. Latomus, pp. 73-74 and 77: “... nihil tamen prohibet quaedam domini dicta et facta, aut etiam diuinitus ad ecclesiae vtilitatem primitus reuelata in nostro canone non haberi ....”

82. Latomus, p. 66: "Ita illud esse diuinum, quod deus semel corpori suo quod est ecclesia dedit. continuat suam legem semper scribens, et scriptam conseruans, in suo mystico corpore, in quo alius exit, alius intrat et singulus quisque defectibilitatem habet. totum vero a spirituali vita, et sacrae legis vera intelligentia nunquam deseritur.”

83. Latomus, p. 77: “Hi humano modo coniecturis innixi, tractantes errare potuerunt, et in quibusdam errantes, a sequentibus reprehensi sunt, quia neque plus sibi credi postulauerunt, quam probabili ratione, aut noui vel veteris testamenti autoritate probauerunt, supponentes, tamen de mysterijs, et sacramentis, et rebus diuinis, quaedam a Christo per apostolos et eorum successores oretenus sine scripto tradita, quae expresse in canone non habentur ...”

84. Latomus, pp. 72-73 and 75-76: “... Hunc [Augustinum] sequuti scolastici, naturalem et moralem, et metaphysicam miscuere Theologiae philosophiam ... Postremo inter christianos, subintrante negligentia, decrescente pietate, Propterea quod ille modus diuina tractandi fusus, liber, et rhetoricus in perniciem vergebat, caepta est certis formis, et regulis, atque dogmatibus tractantium, licentia coerceri, Hinc nata Gymnasia et vniuersitates ..." Also p. 77: "Vltimo loco ponebat scolasticos per quos ceu infimos et nostrae imbecillitati quodammodo magis proporcionatos, ad diuina pergeremus."

85. Latomus, pp. 56-57; also pp. 75-77.

86. Latomus, pp. 67-70: "Dicebat [senex] duplicem esse theologiam, vel potius vnam duobus modis tractari, Verum doctrinae gratia quasi de duabus loquebatur, vnam crassam ac veluti corporalem communem, ac popularem, alteram subtilem, spiritualem, paucorum, et sapientum tantum ...”

87. Latomus, p. 68. Compare with Rummel, Erasmus and his Catholic Critics, vol. 1, p. 83.

88. Latomus, pp. 69-70: “... quos [doctores veteres] si scolasticis ante legat, postea scolasticos aut non leget aut cum nausea leget non sine suo magno malo ... [novitius theologus] eos [authores veteres] ad fidei et christiani dogmatis, regulas legere didicerit ...;” p. 71: "Hunc ducendum putabat ad diuinae sapientiae secreta per suprapositam viam, aut si qua melior inueniri potest”; p. 75: “[Dicebat senex] scolasticos non merito repraehendi ... quamquam in summis, et sententiis atque alijs ad sacrarum literarum, et speculatiuae theologiae noticiam praeparatorijs, hoc [studium theologiae] magis agunt scolastici, quam inter tractandum scripturam, ...”

89. Latomus, p. 69: "Interim tamen ab initio studij Theologici, singulis diebus (si fieri potest) in textu Bibliae aliquamdiu versetur, Ipsum primitus leuiter perlegendo, deinde memoriae commendando singulis diebus certam portionem, incipiens a nouo testamento, In quo [textu biblie] si dubitet, videat doctores et glossas potius, quam se in translationibus, et linguis torqueat, vtens eorum labore, qui circa talia occupantur, ne dum minora scrupulosius scrutatur, ad maiora non perveniat ...”

90. Latomus, p. 69: "nouitius theologus ... post mediocrem grammaticae noticiam non perfunctorie, sed vt dicitur ad viuum in vera dialectica versetur, generalia degustet philosophiae naturalis, Mathematicas attingat disciplinas, maxime Arithmeticam propter 
numeros, diligenter excutiat moralem philosophiam, Metaphisicae quae proxima Theologiae est, gnauiter intendat, Deinde subtilibus speculatiuae Theologiae diligenter incumbat ...” Compare with pp. 70-71 and pp. 75-76.

91. Latomus, p. 75: “[Addebat senex] alia ratione scilicet quod ceu gradu quodam ipsa philosophia vtuntur ad diuina, quod creaturae cognitio ad creatoris noticiam conducere videatur, dum a vestigio et imagine diuinitatis ad ipsam proceditur ...”

92. It is striking, however, that Latomus, who drew abundantly from Augustine's De doctrina Christiana, silently passed over the critical remarks Augustine directed at the dialectici. More specifically, Augustine reproached them on account of their "libido rixandi" and their "puerilis ostentatio decipiendi adversarium" (Augustinus, De doctr. Christ. II, xxxi 48, CCSL 32, pp. 65 1. 5 - 66 1. 7). Humanists such as Mosellanus and Erasmus readily referred to Augustine's explicit criticism but, for obvious reasons, Latomus did not make mention of it.

93. Latomus, p. 74; also pp. 80 and 84.

94. Erasmus, Ratio seu methodus compendio perveniendi ad veram theologiam, ed. Annemarie and Hajo Holborn, Ausgewählte Werke (1933; München: Beck, 1964), p. 303 l. 34-37: “. .. unde coepit in aliquot iam academiis parcius ac moderatius haberi, velut apud Anglos in Cantabrigiensi, apud Brabantos in Lovaniensi. Nec ideo minus florent haec studia, sed verius florent.”

95. On scholastic theology and piety: Latomus, pp. 57-58 and 61. Compare Rummel, Erasmus and his Catholic Critics, vol. 1, p. 76.

96. Latomus, p. 61: "Prior illa magis est ad pietatem dispositio, quam absoluta pietas... Non tamen credere debes continuo theologum esse, qui perfecta pietate pollet, et si talis finem theologiae sit assequutus, quia teste Hieronymo, datur aliquando sancta rusticitas... Vnde concluditur aliud esse theologum quam ardere rapi, amare, licet eum finem appetat theologia."

97. Latomus, p. 61.

98. Latomus, p. 48. Compare with p. 55.

99. I will explain at further length how Latomus interpreted the ideas of the Church Fathers concerning the study of biblical languages.

100. Latomus, pp. 48-49.

101. Latomus, p. 49.

102. Latomus, p. 56.

103. Rummel, Erasmus and his Catholic Critics, vol. 1, p. 76.

104. Latomus, p. 66, with an obvious reference to 1 Cor 14:5.19.

105. Latomus, pp. 66-67. Compare with Rummel, Erasmus and his Catholic Critics, vol. 1, p. 81.

106. Latomus, p. 55. Compare with Augustinus, De doctr. Christ. II, xiii 19; xv 22, CCSL 32, pp. 44 l. 1 - 45 l.10; 48 l. 30-31.

107. Latomus, p. 55, with, among others, a literal quotation from Johannes Chrysostomus, In Matthaeum homilia 8. Versio Anniani Celedensis, ed. J.-P. Migne, PG, 58 (Paris: Migne, 1860) c. 1024. Also: Augustinus, De doctr. Christ. II, xv 22, CCSL 32, pp. 47 l. 3 - 48 l. 30. 
108. Latomus, pp. 55-56.

109. With a reference to Augustinus, De doctr. Christ. II, xi 16, CCSL 32, p. 42 1. 12-14.

110. Latomus, p. 56.

111. Latomus, p. 51: "Nam vt nunc multi sunt vtriusque linguae periti conducemus dato bono stipendio aliquem, qui a iure ciuili tollat graeca, et latina ponat, et in medicina similiter, atque Theologia, hoc vtili compendio redimentes tempus, et tedium discendi graece, hebraice, aut caldaice, interim horas melius collocabimus.” With a possible allusion to Augustinus, De doctr. Christ. II, xxxix 59, CCSL 32, pp. 72 l. 24 - 73 l. 31. Also: Latomus, p. 64: “... haec senex dicebat, non a linguis iuuenes abducens, sed ne hi qui eas [linguas] non habent, aut commode assequi nequeunt, rerum diuinarum desperent scientiam, Addebat senex, sibi videri quod legis euangelicae substantia nullius linguae apicibus includeretur, sic quod apices illos aut literas nesciens necessario legem nesciat ...;" further: pp. 63, 66-67; and p. 69: "In quo [textu biblie] si dubitet, videat doctores et glossas potius, quam se in translationibus, et linguis torqueat, vtens eorum labore, qui circa talia occupantur, ne dum minora scrupulosius scrutatur, ad maiora non perueniat ...”

112. Latomus, p. 63: “ALB. Ex hijs dictis concludi videtur linguas Theologo non esse necessarias ad diuinarum rerum cognitionem assequendam, quare ergo dicit Augustinus de doctrina Christiana, li .ij. Latinae linguae homines et duabus alijs habent opus, ad divinarum scripturarum cognitionem, graeca et hebraea'.” Non-literal quotation of Augustinus, De doctr. Christ. II, xi 16, CCSL 32, p. 42 1. 2-4.

113. Rummel, Erasmus and his Catholic Critics, vol. 1, p. 79.

114. Latomus, p. 63.

115. Latomus, p. 63, freely quoted from Augustinus, De doctr. Christ. II, xi 16, CCSL 32, p. 42 l. 5-6.18-26.

116. Latomus, pp. 63-64, with an almost literal quotation from Augustinus, De doctr. Christ. II, xiii 19, CCSL 32, p. 44 1. 4-5. Possible allusions also to Augustinus, De doctr. Christ. II, xii 18, CCSL 32, p. 44 1. 33-40.

117. Latomus, p. 64: "Igitur quod hunc locum concludens dicit Augustinus, ignota quae ex alienis veniunt, aut quaerenda sunt ab earum linguarum hominibus, aut linguae eaedem si ocium est, et ingenium, ediscendae, aut plurium interpretum consulenda collatio est, Attende hanc disiunctionem, nam primo possimus scientes linguas interrogare, qui hoc tempore solito plures sunt, secundo linguas discere, tertio interpretationes conferre, et tandem ex istis non concludi theologo linguas simpliciter necessarias...” Also an almost literal quotation from Augustinus, De doctr. Christ. II, xiv 21, CCSL 32, p. 46 l. $4-7$.

118. Latomus, p. 64.

119. Latomus, pp. 68-71.

120. With a quotation from Augustinus, De doctr. Christ. IV, vi 10, CCSL 32, pp. 122 l. 34 - 123 1. 39 and a rather loose reference to the following passage taken from Augustinus, De doctr. Christ. IV, vii 11, CCSL 32, p. 123 1. 1-28, particularly l. 25-28. Compare with Augustinus, De doctr. Christ. IV, xxviii 61, CCSL 32, pp. 164 l. 6 - 165 l. 10.

121. Latomus, pp. 60-61.

122. Latomus, pp. 78-83. 
Wim François / Petrus Mosellanus and Jacobus Latomus /47

123. Rummel, Erasmus and his Catholic Critics, vol. 1, pp. 85-87.

124. Latomus, p. 77: "Per scolasticos ... ad divina pergeremus."

125. Compare with Gielis, Scholastiek en Humanisme, pp. 375-76. 